\title{
The Effect of Using Video Technology on Improving Reading Comprehension of Iranian Inter- mediate EFL Learners
}

\author{
Amir Mohammadian ${ }^{1}$, Amin Saed $^{1 *}$, Younes Shahi $^{2}$ \\ ${ }^{1}$ Chabahar Maritime University, Iran, \\ Faculty of Management and Humanities Chabahar Maritime University, Chabahar, Iran
}

Corresponding Author: Amin Saed, E-mail: amin.saed@cmu.ac.ir

\section{ARTICLE INFO}

Article history

Received: December 02, 2017

Accepted: February 05, 2018

Published: April 30, 2018

Volume: 9 Issue: 2

Advance access: March 2018

Conflicts of interest: None

Funding: None

\section{Key words:}

Reading Comprehension,

Video Materials,

Computer Assisted

ABSTRACT

With the development of educational technology, the concept of technology-enhanced multimedia instructions is using widely in the educational settings. Technology can be employed in teaching different skills such as listening, reading, speaking and writing. Among these skills, reading comprehension is the skill in which EFL learners have some problems to master. Regarding this issue, the present study aimed at investigating the effect of video materials on improving reading comprehension of Iranian intermediate EFL learners. A Longman Placement Test was administered to 30 EFL learners to ensure that learners are at the same level of proficiency. The students were chosen from the state high schools in Chabahar. The participants were regarded as intermediate learners and were divided into two groups (one experimental group and one control group). Then, a pre-test of reading comprehension was administered to assess the participants' reading comprehension. The participants of experimental group used video files to improve their reading comprehension while the control group received conventional approaches of teaching reading comprehension. Finally, all the participants were assigned a 40-item multiple-choice reading comprehension post-test. The results of the study indicated that video materials had a significant effect on promoting reading comprehension of Iranian intermediate EFL learners a significant effect $(p=.000,<.05)$.
\end{abstract}

Authentic Material

\section{INTRODUCTION}

Recently, because of the significance of reading skill in learning a foreign language, substantially far more attention is assigned to the studies in the area of reading comprehension. These studies indicated that students typically encounter some difficulties in getting meaning from written texts even after years of getting to know a foreign language (Grabe \& Stoller, 2013). Moreover, the assumption that reading comprehension is a cognitive, complicated, internal and imperceptible actin which happens within the mind of the reader (Bernhardt, 1991) prompts the multifaced design of reading comprehension in its different areas. This lack of good appreciation is accelerated by the vital role of reading in the process of comprehension. According to Ahmadi (2013) reading comprehension plays an important role in the process of learning a foreign or second language and it must be accentuated in different parts of the process. Generally, the debility of the EFL learners to efficaciously read the written texts may be ascribes to an assortment of reasons. Factors like unique elements within the written text, absence of enough familiarity with the content and the schemata of the target language text, incapability of EFL language learners' in in comprehending the texts, shortage of adequate reading methodologies, obscure vocabularies, sophisticated sentence structures, and finally the setting of communication between the writer and the reader are cases of the wellspring of that difficulty (Wood, Motz, \& Willoughby, 1998).

In the conventional methods of language teaching, the instructors for the most part instruct just through text books which is not fascinating for students. Therefore, EFL learners confront some difficulties in their reading comprehension as a result of factors such as reading strategies, absence of motivation and lack of good materials. So, foreign language teachers have to appoint different materials and tools with the intention to be exciting, up-to-date and efficient. These can be met with incorporating technology in eucatinal settings so that, technology can enhance learners' motivation to take part effectively in classes. Studies demonstrated that there is an incredible connection between language- learning motivational elements and exploiting technology. By using technology, teachers access a broad range of rich target language input which is not accessible in regular classes. Despite of many studies conducted in this area, but EFL learners still have some difficulties in reading comprehension. So, in this study we aimed at investigating the effectiveness of using video technology on improving reading comprehension of Iranian intermediate EFL learners and answer the fallowing question: 
RQ. Does learning through video technology have any significant impact on improving reading comprehension of Iranian intermediate EFL learners?

\section{LITERATURE REVIEW}

There are four language skills that should be trained to have capability in learning a foreign language, i.e.: listening, speaking, reading and writing. Normally, the language learning process is commenced from listening-speaking-reading and the last one is writing (Richards \& Rodgers, 1986). In the communicative, learner-centered and interactive system of language learning and teaching, foreign language learners require to learn four skills for their educational accomplishment. Among the language skills, reading comprehension is taken into consideration as a crucial skill in so many Foreign Language (L2) academic contexts. As Chastain (1988) mentioned "reading is a basic and complementary skill in language learning” (p. 216). Consequently, EFL learners require desiarble reading capabilities in English as their Second or Foreign Language (EFL/ESL) to enlarge their understanding of the culture, language, and global perspectives. Undoubtedly, reading comprehension within the area of EFL contexts depicts dynamic processes by which a second language learner is effectively occupied with fruitful apprehension of the target content because s/he could appropriately decipher the writer's intended meaning. This comprehension potentiality is not a passive state, but it is an active process which often need to be empowered and expanded. Grabe and Stoller (2013) considered reading comprehension as a sophisticated cognitive process which varies in multiple approaches depending on motivation, goals, activities, and language strategies of the EFL learners. According to Wilhelm and Li (2008) (Beare, 2008)"For most second language learners who are already literate a previous language, reading comprehension is primarily a matter of developing appropriate and efficient comprehension strategies"(p.99). Subsequently, exploiting authentic materials in the educational contexts can be an excellent choice to enhance reading comprehension capabilities of foreign language learners.

\section{Authentic Material}

To start with, Martínez (2002), regarded authentic material as "a Material designed for native speakers of English." Furthermore, Nunan (1999), characterizes authentic or real materials "' as [...] genuine communication and not specifically written for the goal of language teaching." In line with what formerly said, the employment of authentic material for this study have an important role, due to the fact that, EFL learners will be exposed to video materials in which they can interact and learn the language that native-like speakers utilized in actual contexts, and not with the language designed for a common lesson. Also, Yuanyuan \& Lingzhu (1997) declared some short definitions for authentic or real materials. "They are real language"; "produced for the native speakers"; "designed without the teaching purposes". As it is declared by these scholars, authentic materials are replete with offering real situations that are not designed for language teaching, but can assist the EFL or ESL learners getting different expressions and vocabulary items, thus interact with the language as it is employed in a real situation. Another significant concept concerning with authentic materials has to deal with Rogers \& Medley's (1988) expression who exploit the term authentic material as "language samples. that reflect a naturalness of form, and an appropriateness of cultural and situational context that would be found in the language as used by the native speakers"(p.468).

\section{Advantages of Using Video Materials in ELT}

Authentic and real Materials are fabulous instruments to encourage the EFL learners to learn a language, utilized by instructors as some scholars declare (Ramirez, cited by Gonzales Moncada, 2004). As a matter of fact, video materials are apparatuses designed to teach a foreign language to master the foreign language, which can be applied in EFL contexts depending on the purpose of the course. William \& Lutes (2000) mentioned that:

A great benefit is that video materials can concentrate on information that cannot be simply presented in a traditional classroom because of constraints such as size, location, costs, etc. In the ESL classroom, this can be something as simple as access to native speaker language in a natural context. However, because watching video is a passive activity, it needs to be used as part of an active learning strategy in order to be an effective tool, particularly in holding the attention of students. Since dual coding has been proven to enhance encoding by learners, video materials are an effective delivery system because they contain a combination of visual and aural information (p.25).

The application of video materials in the educational settings can be a fabulous strategy, so that, EFL learners are provided with a lot of advantages when they are employed in combination with a dynamic learning strategy. Using videos in instructional settings permits the second language learners to get entry to multiple information when listening to the files. As a matter of fact, the learners can listen and observe what is going on at the same time. Miller (2003) pointed out that Non-verbal behavior or paralinguistic aspects of the spoken text are now reachable to the EFL learners, so the learners can enhance their knowledge in the educational context. Many foreign language learners watch video files outside of class time, but few of them regard them as a suitable opportunity to develop their reading comprehension. Therefore, these statements display that watching video materials is so helpful for EFL learners to augment their knowledge of the foreign language outside the classroom. Furthermore, based on Beare's statement (2008), videos assist the EFL learners to be familiar with their learning process. They permit the students to gain an immediate feedback and this aspect made videos more effective and efficient than "simple teacher correction". Harmer (2001) declared that one of the most important benefits of video materials is that foreign language learners not only can listen the expressions but also, they can observe and interact with them in order to comprehend. Actually, video materials offer some visual clues such as gestures which assist the EFL and ESL learners to go beyond 
of what they listen, and also to interpret the expressions in a deeper manner. Due to the fact that EFL learners can observe the language in the real situation from natural contexts; they can make a connection between words and images which assist them to scrutinize their own use of the language.

Marzban (2010) investigated the effect of computer assisted language learning on improving reading comprehension of Iranian EFL learners. To this end, 60 EFL learners were participated in the study. Based on the nature of the study, an experimental design was used. The experimental group used CALL to enhance their reading comprehension and the control group used traditional methods of teaching reading. The results showed that the use of computer assisted educational techniques can improve reading comprehension of foreign language learners.

Kim (2015) investigated the effect of the video materials on improving listening comprehension of foreign language learners. 86 participants were assigned to three groups based on the results of their placement test scores. Paired sample t-tests and One-way ANOVA were used to show the significant differences. The Learners' listening comprehension improved significantly after learning with video materials. Furthermore, the promotion of the intermediate and advanced participants was more than those of the low proficiency group.

Video materials help the foreign language learners to expand degree of their proficiency through the exclusive factors that the real discourse contains. Van Duzer (1998) declared that the real language contains rephrasing, hesitations, and various accents. In this way, it should not be amended or simplified to make them easier for the foreign language learners. Moreover, Van Duzer (1998) and Martinez (2002) stated that video materials applied in the educational settings, provide real situations, intonation, and real pronunciation and permit the learners to be exposed to a real context, as. Ramal (2006) said that using video materials in an EFL ssetting can motivate students, so that they can experience real feelings to expand their understanding about the situation of the video. So, in this study, the researchers exploited video materials to promote reading comprehension of Iranian intermediate EFL learners.

\section{METHODOLOGY}

\section{Participants of the Study}

In this study, the participants were 30 students, just male students, with the same level of proficiency. The students participated in the current study, were selected from state high schools in Chabahar, Iran and all of the students had the same amount of exposure to English language courses. All participants were native speakers of Persian and ranged between 16 and 18 years in age. They formed up a representative sample of Iranian EFL learners.

\section{Research Instruments}

To answer the research question of the study, three tests were utilized: first, the subjects participated in a Longman place- ment test. Then, a pre-test of reading comprehension was administered to determine the student' level of reading comprehension at the start, and the third test was the post-test for each group to assess the effect of video technology on improving reading comprehension of the participants. Finally, SPSS version $23^{\text {rd }}$ was used to analyze data. SPSS statistics software was used to compare the results of the pretests and the posttests prior to and after the experiment.

\section{Procedure}

The study was conducted within three months in the educational year of 2016-2017. During this period, the study was carried out as a form of classroom action research. It lasted for 15 weeks, three sessions in each week. First of all, this study selected two groups each of which having 15 candidates from state high schools in Chabahar. Then, a Longman placement test was administered to ensure their level as intermediate. Then, they were divided into two groups (Experimental and Control Group) After that, a pretest of reading comprehension was administered to both groups before the study to ensure both groups equivalence and homogeneity. The number of items in the pre-test of reading comprehension was 40 items in multiple choice format. Since there were a total of 40 items, the maximum score was decided to be 40 , i.e. one mark for recognizing each test item correctly and zero for incorrect recognition. Next, the first group received regular instruction. According to the regular instruction, participants in the control group were given little communicative opportunities to practice the reading skills. Conversely, the second group used educational video files to improve their reading comprehension. Finally, a posttest of reading comprehension was administered to both groups to assess their reading comprehension ability at the end of the study and to compare the results of the experimental group with the results of the control group. The number of items and scoring procedure of this post-test were the same as the pre-test.

\section{RESULTS}

The quantitative analysis of the collected data was analyzed with the aid of SPSS software. The data obtained from 30 participants of the study were analyzed using descriptive statistics, paired-samples t-test, and independent samples t-test. The standard of $\mathrm{p}<.05$ was used in order to depict the significance throughout the study.

\section{Performance of Groups in Reading Comprehension Pre-test}

Descriptive statistics and independent samples t-test were run to analyze the data gathered from pre-test of reading comprehension. The results of the pre-test performance of the participants are shown in Table 1 and 2

As it could be seen in Table 1, the mean scores of the control group and the excremental group are 18.73 and 19.07 respectively. As the table depict, the mean difference size is small among the two groups, but in order to examine wheth- 
er the mean difference is small or big at the beginning of the study, a t-test was run in order to compare the mean scores. As Table 2 shows, the $\mathrm{P}$ value is more than $0.05(0.68>0.05)$ which indicates that both groups are homogenous and there are no statistically significant differences between the control and experimental groups on the pretest in their overall reading performance.

\section{Results of Posttest of the Control and Experimental Groups}

The results obtained from the post-test are presented in Table 3 and Table 4. Moreover, another independent sample t-test was run in order to investigate whether the treatment given to the experimental groups had any effects on their language proficiency and to examine if the participants in these groups performed significantly different on their posttest.

The computed reading performance development mean and standard deviation of the participants in the control group equaled 19.80, and 2.11, respectively. And the computed reading performance development mean and standard deviation of the participants in the treatment group equaled 23.80 , and 1.61, respectively. An inspection of the mean scores showed that there was a considerable difference between the treatment group and the control group in terms of overall reading comprehension performance. Moreover, the independent-samples t-test analysis showed that this difference was statistically significant $(p=0.000)$. Hence, it can be surely said that there were statistically significant differences between the experimental and control groups on the post- test in overall reading in favor of the experimental group. So, it can be concluded that the results approved the significant impact of using video technology in improving reading comprehension of Iranian intermediate EFL learners.

\section{Comparing the Pre- and Post-tests}

Finally, paired-samples t-test was employed to demonstrate the pre-test and post-test differences within experimental and control groups (intra-group). This analysis was used to show how experimental and control groups' performances have separately changed since the beginning of the study.

\section{Control Group's Performance in Pre- and Post-tests}

The comparison of the pre- and post-tests of the control group indicated some achievements in reading proficiency mean scores (Table 5) of the participants. The pre-test and post-test mean values of 18.73 and 19.80 shows development in the participants' reading proficiency. The estimated $\mathrm{p}$ value is more than $0.05(0.19>0.05)$ (Table 6). As a result,

Table 1. Descriptive statistics for the results of reading comprehension pre-test

\begin{tabular}{lllccc}
\hline & \multicolumn{5}{c}{ Group statistics } \\
\hline & Groups & N & Mean & Standard deviation & Standard error mean \\
\hline pre_pre_Exp_Cont & Control & 15 & 18.73 & 2.374 & 0.613 \\
& Experimental & 15 & 19.07 & 2.120 & 0.547 \\
\hline
\end{tabular}

Table 2. Independent-samples $t$-test results for the pre-test of the treatment and control groups

\begin{tabular}{|c|c|c|c|c|c|c|c|c|c|}
\hline \multicolumn{10}{|c|}{ Independent samples test } \\
\hline & \multicolumn{2}{|c|}{$\begin{array}{c}\text { Levene's test } \\
\text { for equality of } \\
\text { variances } \\
\end{array}$} & \multirow[t]{3}{*}{$\mathbf{t}$} & \multirow[t]{3}{*}{ df } & \multicolumn{3}{|c|}{ t-test for equality of means } & & \\
\hline & \multirow[t]{2}{*}{$\mathbf{F}$} & \multirow[t]{2}{*}{ Sig. } & & & \multirow[t]{2}{*}{$\begin{array}{c}\text { Sig. } \\
\text { (2-tailed) }\end{array}$} & \multirow[t]{2}{*}{$\begin{array}{c}\text { Mean } \\
\text { difference }\end{array}$} & \multirow[t]{2}{*}{$\begin{array}{l}\text { Standard } \\
\text { error } \\
\text { difference }\end{array}$} & \multicolumn{2}{|c|}{$\begin{array}{l}95 \% \text { confidence } \\
\text { interval of the } \\
\text { difference }\end{array}$} \\
\hline & & & & & & & & Lower & Upper \\
\hline \multicolumn{10}{|l|}{ pre_pre_Exp_Cont } \\
\hline $\begin{array}{l}\text { Equal variances } \\
\text { assumed }\end{array}$ & 0.096 & 0.758 & -0.406 & 28 & 0.688 & -0.333 & 0.822 & -2.017 & 1.350 \\
\hline $\begin{array}{l}\text { Equal variances } \\
\text { not assumed }\end{array}$ & & & -0.406 & 27.648 & 0.688 & -0.333 & 0.822 & -2.018 & 1.351 \\
\hline
\end{tabular}

Table 3. Group statistics of reading comprehension post-test

\begin{tabular}{lllccr}
\hline & \multicolumn{5}{c}{ Group statistics } \\
\hline & Groups & N & Mean & Standard deviation & Standard error mean \\
\hline post - post_Exp_Cont & Control & 15 & 19.80 & 2.111 & 0.545 \\
& Experimental & 15 & 23.80 & 1.612 & 0.416 \\
\hline
\end{tabular}


Table 4. Results of independent-samples t-test for reading comprehension post-test of both groups

\begin{tabular}{|c|c|c|c|c|c|c|c|c|c|c|}
\hline \multicolumn{11}{|c|}{ Independent samples test } \\
\hline & & \multicolumn{2}{|c|}{$\begin{array}{c}\text { Levene's test } \\
\text { for equality of } \\
\text { variances }\end{array}$} & \multirow[t]{3}{*}{$\mathbf{t}$} & \multirow[t]{3}{*}{ df } & \multicolumn{3}{|c|}{ t-test for equality of means } & & \\
\hline & & \multirow[t]{2}{*}{$\mathbf{F}$} & \multirow[t]{2}{*}{ Sig. } & & & \multirow[t]{2}{*}{$\begin{array}{c}\text { Sig. } \\
\text { (2-tailed) }\end{array}$} & \multirow[t]{2}{*}{$\begin{array}{c}\text { Mean } \\
\text { difference }\end{array}$} & \multirow[t]{2}{*}{$\begin{array}{l}\text { Standard } \\
\text { error } \\
\text { difference }\end{array}$} & \multicolumn{2}{|c|}{$\begin{array}{l}95 \% \text { confidence } \\
\text { interval of the } \\
\text { difference }\end{array}$} \\
\hline & & & & & & & & & Lower & Upper \\
\hline \multirow[t]{2}{*}{$\begin{array}{l}\text { post_post_- } \\
\text { Exp_Cont }\end{array}$} & $\begin{array}{l}\text { Equal variances } \\
\text { assumed }\end{array}$ & 0.685 & 0.415 & -5.832 & 28 & 0.000 & -4.000 & 0.686 & -5.405 & -2.595 \\
\hline & $\begin{array}{l}\text { Equal variances } \\
\text { not assumed }\end{array}$ & & & -5.832 & 26.187 & 0.000 & -4.000 & 0.686 & -5.409 & -2.591 \\
\hline
\end{tabular}

Table 5. Results for the Pre-test and Post-test of the control group

\begin{tabular}{llcccc}
\hline \multicolumn{5}{c}{ Paired samples Ssatistics } \\
\hline Pair 1 & Mean & N & Standard deviation & Standard. error mean \\
& Pre_Control & 18.73 & 15 & 2.374 & 0.613 \\
& Post_Control & 19.80 & 15 & 2.111 & 0.545 \\
\hline
\end{tabular}

Table 6. Paired-samples t-test results for the pre-test and post-test of the control group

\begin{tabular}{|c|c|c|c|c|c|c|c|c|}
\hline \multirow[t]{4}{*}{ Mean } & \multirow{4}{*}{$\begin{array}{l}\text { Standard } \\
\text { deviation }\end{array}$} & \multicolumn{4}{|c|}{ Paired samples test } & \multirow{4}{*}{$\mathbf{t}$} & \multirow{4}{*}{ df } & \multirow{4}{*}{ Sig. (2-tailed) } \\
\hline & & \multicolumn{4}{|c|}{ Paired differences } & & & \\
\hline & & \multirow[t]{2}{*}{$\begin{array}{l}\text { Standard } \\
\text { error mean }\end{array}$} & \multicolumn{3}{|c|}{$\begin{array}{l}95 \% \text { confidence interval of the } \\
\text { difference }\end{array}$} & & & \\
\hline & & & Lower & Upper & & & & \\
\hline Pair 1 & -1.067 & 3.058 & 0.790 & -2.760 & 0.627 & -1.351 & 14 & 0.198 \\
\hline $\begin{array}{l}\text { Pre_} \\
\text { Control - Post_ } \\
\text { Control }\end{array}$ & & & & & & & & \\
\hline
\end{tabular}

it can be said that participants of control group did not progress significantly in their reading comprehension.

\section{Experimental Group's Performance in Pre-test and Post- test}

To determine extent of change fostered by the application of the proposed program from the pre- test to the post- test for the experimental group, $t$ - tests for paired samples were employed. These t- tests aimed at comparing the mean scores of the experimental group on the pre- test and the post- test in overall reading performance. Table 7 and table 8 show the interpretations of the tests in more detail.

Table 8 indicates that there are statistically significant differences at 0.01 levels in overall reading between the mean scores of the experimental group on the pretest and the post- test in favor of the post- test scores since the estimated $\mathrm{p}$ values 0.00 was lower than $0.05(0.00<0.05)$. So, it can be concluded that, video technology had significant effect on improving reading comprehension of Iranian intermediate EFL learners.

\section{DISCUSSION}

Regarding the research question stated at the outset of the study, the results depicted that using video technology had a significant impact on promoting reading comprehension of Iranian intermediate EFL learners. Indeed, it can be stated that the mean score results of the reading test, which were administered after using video technology, displayed the fact that the participants of experimental group $(\mathrm{P}<0.05)$ performed significantly better than those in the control group. Therefore, application of video materials in teaching reading comprehension proved to be significant. It also worth mentioning that, although both the experimental and control groups received the same amount of time and instruction, it was the experimental group which showed higher improvements and their mastery of the reading proficiency was gained from the application of video technology. The findings of this study are compatible with research results and findings of the existing studies stated in the review of literature related studies (Marzban,2011; Harmer, 2001; Martinez, 2002, Ramal, 2006; Kim, 2015). The results of this study are congruent with those of Kim (2015) who stated that video materials had a significant impact on EFL learners' reading 
Table 7. Descriptive statistics for the results of the pre-posttest in the experimental group

\begin{tabular}{lcccc}
\hline & \multicolumn{4}{l}{ Paired samples statistics } \\
\hline & Mean & N & Standard deviation & Standard error mean \\
\hline Pair 1 & 19.07 & 15 & 2.120 & 0.547 \\
& 23.80 & 15 & 1.612 & 0.416 \\
Pre_Experimental & & & & \\
Post_Expermental & & & & \\
\hline
\end{tabular}

Table 8. Paired-samples t-test for the results of the pre-posttest in the experimental group

\begin{tabular}{|c|c|c|c|c|c|c|c|c|}
\hline \multirow[t]{4}{*}{ Mean } & \multirow{4}{*}{$\begin{array}{l}\text { Standard } \\
\text { deviation }\end{array}$} & \multirow{2}{*}{\multicolumn{2}{|c|}{$\begin{array}{l}\text { Paired samples test } \\
\text { Paired differences }\end{array}$}} & & & \multirow[t]{4}{*}{ t } & \multirow[t]{4}{*}{ df } & \multirow[t]{4}{*}{ Sig. (2-tailed) } \\
\hline & & & & & & & & \\
\hline & & \multirow[t]{2}{*}{$\begin{array}{c}\text { Standard } \\
\text { error mean }\end{array}$} & \multicolumn{2}{|c|}{$\begin{array}{c}95 \% \text { confidence } \\
\text { interval of the } \\
\text { difference }\end{array}$} & & & & \\
\hline & & & Lower & Upper & & & & \\
\hline Pair 1 & -4.733 & 3.348 & 0.864 & -6.587 & -2.879 & -5.475 & 14 & 0.000 \\
\hline $\begin{array}{l}\text { Pre_- } \\
\text { experimental - Post_ } \\
\text { Experimental }\end{array}$ & & & & & & & & \\
\hline
\end{tabular}

comprehension. Authentic materials provide a real situation for foreign language learners to communicate more easily. Actually, for successful comprehending, the EFL learner should apply many techniques like videos to recreate and understand the anther's intended meaning. In this respect, Terrell (1993) underscored the integration of videos for integrated language learning by giving an example of reading comprehension. He stated that: “... reading comprehension training with [authentic] video materials for intermediate students gives them experiences that cannot be duplicated in traditional classroom limited to instructor/student interaction" (p.22). Actually, using video materials in educational settings can motivate students, because they can experience real feelings to complete their understanding about the situation of the video. Also, authentic materials like videos, can provide a real environment for the fulfilment of theoretical tenets of communicative approach which concentrates on the social interaction and cultural aspect of a language. So, watching videos is an opportunity for students to expand their reading comprehension.

\section{CONCLUSION}

The purpose of the present study was to identify the effect of using video technology on developing reading comprehension of Iranian intermediate EFL learners. The results of this study revealed that video technology had a significant impact on reading comprehension ability of Iranian intermediate EFL learners. Taking into account the fact that using videos can be considered as one of the effective instructional materials in teaching reading to EFL learners, it can firmly be argued that proper use of this technology would significantly assist teachers and instructors to promote high school students' reading comprehension. The results of the current study assist the high school students to select useful reading strategies and materials in the classroom to improve their reading comprehension. Also, using authentic materials in educational settings can enhance the EFL learner' motivation through the process of learning a foreign language.

\section{REFERENCES}

Ahmadi, M. R. (2013). The importance of metacognitive reading strategy awareness in reading comprehension. English Language Teaching(6), 235-244. doi:10.5539/ elt.v6n10p235

Beare, K. (2008). Choosing props for the ESL/EFL classroom, props in class. Retrieved from esl.about.com/od/ esleflteachingtechnique/a/t_props_2.htm

Bernhardt, E. (2005). Progress and procrastination in second language reading. Annual Review of Applied Linguistics, 25, 133-150. Retrieved from http://dx.doi.org/10.1017/ S0267190505000073

Chastain, K. (1988). Developing second language skills: theory and practice (third ed.). United State of America: Harcourt Brace Jovanovic, Inc.

González- Moncada, A. (2006). On materials use training in EFL teacher education: some reflections. Retrieved August 22, 2008, from http:// www.scielo.org.co/scielo.php?script $=$ sci_arttext\&pid=S1657-07902006000100008\&lng=en\&nrm $=$ iso

Grabe, W., \& Stoller, F. L. (2013). Teaching and researching reading ( $\left.2^{\text {nd }} e d.\right)$. London: Routledge Press.

Harmer, J. (2001). Teaching with video. In A. Pearson Education Limited. Practice of English language teaching (pp. 282). England: Editorial logman.

Kim, H. (2015). Using Authentic Videos to Improve EFL Students Listening Comprehension. International Journal of Contents, 11(4), 15-24. doi:10.5392/ ijoc.2015.11.4.015 
Li, H. (2008). Exploring pedagogical reasoning: Reading strategy instruction from two teachers' perspectives. The Reading Matrix, 5(1), 96-110.

Martinez, A. (2002). Authentic Materials: An Overview. Retrieved April 26, 2008, from http://www3.telos.net/linguisticissues/authenticmaterials.html.

Marzban, A. (2011). Improvement of reading comprehension through computer-assisted Language learning in Iranian intermediate EFL students. Procedia Computer Science, 3, 3-10. doi:10.1016/j.procs.2010.12.003

Miller, L. (2003). Developing listening skills with authentic materials. Retrieved May 5, 2008, from http://www.elthillside.com/up/files/article4.doc.

Nunan, D. (1999). Second Language Teaching \& Learning. Canada: Heinle \& Heinle.

Rammal, S. (2006). Using video in the EFL classroom. Retrieved May 5, 2008, from http:/www3.telus.net/linguisticsissues/using\%20video.

Richards, J. C., \& Rodgers, T. (1986). Approaches and Methods in Language Teaching. Cambridge: Cambridge University Press.

Rogers, C., \& Medley, F. J. (1988). Language with a purpose: using Authentic Materials in the Foreign Language. Annals, 21, 267-468.

Terrell, T. (1993). Comprehensible input for intermediate foreign language students via video. Journal of Language Learning Technologies, 26(2), 17-23.

Van Duzer, C. (1998). improving ESL learners' listening skills: At the workplace and beyond. Retrieved March 23, 2008, from http:/www.cal.org/caela/esl_resources/ digests/LISTENQA.html

Wilhelm, L. H. (2008). Exploring pedagogical reasoning: Reading strategy instruction from two teachers' perspectives. The Reading Matrix, 8(1), 96-110.

William, R. T., \& Lutes, P. (2000). Using video in the ESL classroom. Retrieved March 23, 2008, from http://www. takamatsu-u.ac.jp/library/06_gaku

Wood, E., Motz, M., \& Willoughby, T. (1998). Examining students' retrospective memories of strategy. Journal of Educational Psychology, 90(4), 698-704. doi:10.1037/0022-0663.90.4.698

Yuannyun, Z., \& Lingzhu, J. (1997). The Use of Authentic Materials in Teaching EFL Listening. Retrieved 12 , 2010, from http://www.hltmag.co.uk/aug10/mart03.htm. 